\title{
Diffusive emission of methane and carbon dioxide from two hydropower reservoirs in Brazil
}

\author{
Marcelino, AA. ${ }^{a *}$, Santos, MA. ${ }^{b}$, Xavier, $V L{ }^{b}$, Bezerra, CS. ${ }^{b}$, Silva, CRO.$^{b}$, \\ Amorim, MA. ${ }^{b}$, Rodrigues, $R P^{b}{ }^{b}$ and Rogerio, $J P^{b}$ \\ aPrograma de Planejamento Energético - PPE, Instituto Alberto Luiz Coimbra de Pós-Graduação e Pesquisa de Engenharia \\ - COPPE, Universidade Federal do Rio de Janeiro - UFRJ, Centro de Tecnologia, bloco C, sala 211, CEP 21949-972, \\ Cidade Universitária, tha do Fundão, Rio de Janeiro, RJ, Brazil \\ 'Laboratório de Energias Renováveis e Estudos Ambientais - LEREA, Centro de Tecnologia, bloco I, sala I 211, \\ CEP 21949-972, Cidade Universitária, Ilha do Fundão, Rio de Janeiro, RJ, Brazil \\ *e-mail: aamarcelino@gmail.com
}

Received: July 16, 2013 - Accepted: May 15, 2014 - Distributed: May 31, 2015

(With 4 figures)

\begin{abstract}
The role of greenhouse gas emissions from freshwater reservoirs and their contribution to increase greenhouse gas concentrations in the atmosphere is currently under discussion in many parts of the world. We studied $\mathrm{CO}_{2}$ and $\mathrm{CH}_{4}$ diffusive fluxes from two large neotropical hydropower reservoirs with different climate conditions. We used floating closed-chambers to estimate diffusive fluxes of these gaseous species. Sampling campaigns showed that the reservoirs studied were sources of greenhouse gases to the atmosphere. In the Serra da Mesa Reservoir, the $\mathrm{CH}_{4}$ emissions ranged from 0.530 to $396.96 \mathrm{mg} \cdot \mathrm{m}^{-2} \cdot \mathrm{d}^{-1}$ and $\mathrm{CO}_{2}$ emissions ranged from $-1,738.33$ to $11,166.61 \mathrm{mg} \cdot \mathrm{m}^{-2} \cdot \mathrm{d}^{-1}$ and in Três Marias Reservoir the $\mathrm{CH}_{4}$ fluxes ranged 0.720 to $2,578.03 \mathrm{mg} \cdot \mathrm{m}^{-2} \cdot \mathrm{d}^{-1}$ and $\mathrm{CO}_{2}$ emission ranged from $-3,037.80$ to $11,516.64$ to $\mathrm{mg} \cdot \mathrm{m}^{-2} \cdot \mathrm{d}^{-1}$. There were no statistically significant differences of $\mathrm{CH}_{4}$ fluxes between the reservoirs, but $\mathrm{CO}_{2}$ fluxes from the two reservoirs studied were significantly different. The $\mathrm{CO}_{2}$ emissions measured over the periods studied in Serra da Mesa showed some seasonality with distinctions between the wet and dry transition season. In Três Marias Reservoir the $\mathrm{CO}_{2}$ fluxes showed no seasonal variability. In both reservoirs, $\mathrm{CH}_{4}$ emissions showed a tendency to increase during the study periods but this was not statistically significant. These results contributed to increase knowledge about the magnitude of $\mathrm{CO}_{2}$ and $\mathrm{CH}_{4}$ emission in hydroelectric reservoirs, however due to natural variability of the data future sampling campaigns will be needed to better elucidate the seasonal influences on the fluxes of greenhouse gases.
\end{abstract}

Keywords: hydropower, dissolved organic carbon, greenhouse gas effect, lakes, reservoirs, $\mathrm{CO}_{2}$ emissions.

\section{Emissões difusivas de metano e de dióxido de carbono oriundas de dois reservatórios hidrelétricos}

\begin{abstract}
Resumo
Atualmente, em diversas partes do mundo, tem-se discutido muito sobre a contribuição das emissões de gases de efeito estufa oriundas de reservatórios hidrelétricos. Neste trabalho foram medidos fluxos difusivos de $\mathrm{CO}_{2} \mathrm{e} \mathrm{CH}_{4} \mathrm{em}$ dois grandes reservatórios hidrelétricos neotropicais com diferentes condições climáticas (UHE Serra da Mesa e UHE Três Marias). Utilizamos câmaras flutuantes para estimar os fluxos difusivos de $\mathrm{CO}_{2} \mathrm{e} \mathrm{CH}_{4}$. As campanhas de amostragem mostraram que os dois reservatórios estudados apresentaram-se como fontes emissoras de gases por mecanismo de difusão. No reservatório de Serra da Mesa as emissões de $\mathrm{CH}_{4}$ variaram entre 0,530 e $396,96 \mathrm{mg} \cdot \mathrm{m}^{-2} \cdot \mathrm{d}^{-1} \mathrm{e}$ as emissões de $\mathrm{CO}_{2}$ variaram entre $-1.738,33$ a $11.166,61 \mathrm{mg} \cdot \mathrm{m}^{-2} \cdot \mathrm{d}^{-1}$. No reservatório de Três Marias os fluxos de $\mathrm{CH}_{4}$ variaram entre 0,720 e $2.578,03 \mathrm{mg} \cdot \mathrm{m}^{-2} \cdot \mathrm{d}^{-1}$. Já os fluxos de $\mathrm{CO}_{2}$ variaram de $-3.037,80$ à $11.516,64 \mathrm{mg} \cdot \mathrm{m}^{-2} \cdot \mathrm{d}^{-1}$. Não houve diferença estatisticamente significativa dos fluxos de $\mathrm{CH}_{4}$ entre os reservatórios estudados, entretanto os fluxos de $\mathrm{CO}_{2}$ foram significativamente diferentes. As emissões de $\mathrm{CO}_{2}$ medidas ao longo dos períodos estudados em Serra da Mesa mostrou certa sazonalidade, com distinções entre o período de transição seco e úmido. No reservatório de Três Marias os fluxos de $\mathrm{CO}_{2}$ não apresentaram variabilidade sazonal. Em ambos os reservatórios, as emissões de $\mathrm{CH}_{4}$ apresentaram aumento do fluxo ao longo dos períodos de estudo, mas isso não foi estatisticamente significativo. Estes resultados contribuíram para aumentar o conhecimento sobre a variabilidade das emissões difusivas de $\mathrm{CO}_{2} \mathrm{e}$ $\mathrm{CH}_{4}$ em reservatórios de usinas hidrelétricas. Entretanto, novas campanhas de amostragem serão necessárias para melhor estudar as influências sazonais sobre os fluxos dos gases de efeito estufa.
\end{abstract}

Palavras-chave: hidrelétricas, carbono orgânico dissolvido, gases de efeito estufa, lagos, reservatórios, emissão de $\mathrm{CO}_{2}$. 


\section{Introduction}

Methane $\left(\mathrm{CH}_{4}\right)$ is the most abundant organic gas in Earth's atmosphere and has an important role to tropospheric and stratospheric chemistry, affecting for example, tropospheric ozone, hydroxyl radicals and carbon monoxide concentrations, stratospheric chlorine and ozone chemistry and, through its infrared properties, Earth's energy balance (Cicerone and Oremland, 1988). Wuebbles and Hayhoe (2002) have estimated that up to $0.6 \mathrm{Gt}$ of methane are emitted annually into the atmosphere; moreover about $75 \%$ of this is produced exclusively by strictly anaerobic methanogenic microorganisms present in anoxic environments (Segers, 1998; Whitman et al., 2006).

In the same way $\mathrm{CO}_{2}$ plays an important role not only for atmospheric chemistry but also to the chemistry of the biosphere due to its availability as a carbon source for photosynthesis. $\mathrm{CH}_{4}$ is the third most important greenhouse gas after water vapor and $\mathrm{CO}_{2}$ and has a Global Warming Potential (GWP) 25 times greater than $\mathrm{CO}_{2}$ on a 100 year timescale (IPCC, 2007). According Dlugokencky and Tans (2012) and IPCC (2007) global concentrations of $\mathrm{CH}_{4}$ and $\mathrm{CO}_{2}$ in the atmosphere were $1,775 \mathrm{ppb}$ and $394 \mathrm{ppm}$ while in pre-industrial era no more than $715 \mathrm{ppb}$ and $280 \mathrm{ppm}$, respectively. This trend of increased concentration in the atmosphere is more and more linked to anthropogenic activities such as livestock, changes in land use and mainly energy use (IPCC, 2007).

Hydro power reservoirs as artificial aquatic systems represent an important part of the Earth's continental territory. They have an important role in the aquatic biogeochemistry and have also many effects on the environment. Recently another important negative impact of dam construction has been reported: emission of greenhouse gases generated by flooding organic matter during reservoir formation. Since the beginning of the 1990's several scientists have argued that hydropower reservoirs, as well as natural ecosystems, emit biogenic gases by bubbling and by molecular diffusion (Rudd et al., 1993; Bartlett and Harriss, 1993; Kelly et al., 1997; Hamilton et al., 1995; Abril et al., 2005).

Furthermore, several authors suggest that different environmental variables are related to greenhouse gas emission from a reservoir, such as input of carbon species by rivers and streams (Del Giorgio et al., 1999; Tranvik et al., 2009), meteorological factors (Striegl and Michmerhuizen, 1998; Cole and Caraco, 1998), and biological influences (Dumestre et al., 1999, 2002).

Knowledge of greenhouse gases emissions from hydroelectric reservoirs in Brazil becomes important since $83 \%$ of Brazilian electricity is produced by hydraulic sources (Brasil, 2012) and Brazil is the second largest producer of hydroelectricity, after China (IEA, 2012).

Research conducted by national and international teams has given successive contributions to the understanding of greenhouse gases emissions from Brazilian hydroelectric reservoirs (Rosa et al., 1994, 2003; Guerin et al., 2006; Santos et al., 2006; Roland et al., 2010).
This study presents the results of measurements of $\mathrm{CH}_{4}$ and $\mathrm{CO}_{2}$ diffusive emissions from two large hydroelectric reservoirs at in the Brazilian Cerrado, in an attempt to improve quantity and quality of data available.

\subsection{Site location}

The present study was carried out at the Serra da Mesa Reservoir (15 50' 01,6" S 48 18' 13,6" W), located in the Midwest region of Brazil in the Tocantins River - , Goiás State, and the Três Marias Reservoir ( $18^{\circ} 12^{\prime}$ 50,8" S $45^{\circ} 15^{\prime} 45,9$ " W) located in southeastern Brazil in the São Francisco River - Minas Gerais State, both in the Brazilian Cerrado Biome (central high plain bush country) (see Figure 1).

The Serra da Mesa Reservoir is 15 years old and is the largest by volume in Brazil with 54.4 billion $\mathrm{m}^{3}$, an average surface area of $1,784 \mathrm{~km}^{2}$ and very important in the Brazilian energy scenario with 1,275 MW installed capacity. The Três Marias Reservoir has $396 \mathrm{MW}$ installed capacity and $1,040 \mathrm{~km}^{2}$ flooded area with 21 billion $\mathrm{m}^{3}$ volume and has been working since 1921 .

Serra da Mesa is located approximately $580 \mathrm{~km}$ north of Três Marias. The climate in both reservoirs is classified as tropical seasonal dry winters. The average annual temperature is about $25^{\circ} \mathrm{C}$, however the monthly absolute maximum can reach $40{ }^{\circ} \mathrm{C}$. The rains are concentrated in the period between October to March and may reach zero during the dry season which runs from May to August.

\section{Experimental Methods}

Four sampling campaigns were conducted for each reservoir in order to collect data covering all the hydrologic periods. Sampling sites was undertaken in Três Marias and Serra da Mesa in different seasons (Table 1).

In order to determine the $\mathrm{CH}_{4}$ and $\mathrm{CO}_{2}$ diffusive flux, a PVC chamber with a volume of $1000 \mathrm{~mL}$ and area of $0.047 \mathrm{~m}^{2}$ was placed floating on the water surface. The method was described by Devol $(1988,1990)$ and Bartlett et al. (1988, 1990). All the samples were taken in vegetation-free areas both in the middle of reservoir and near the edges. One gas sample was taken from the chamber initially after 2, 4 and 8 minutes, counting from the initial moment when the chamber was placed on the water/air interface. A single sampling was used for each floating chamber point. The air samples inside the chambers $(30 \mathrm{~mL})$ were collected by $60 \mathrm{~mL}$ polyethylene syringes and transferred to glass gasometric ampoules. All samples were taken between 9:00 and 17:00 h, local time.

$\mathrm{CH}_{4}$ and $\mathrm{CO}_{2}$ concentrations were determined in a field laboratory within 8 hours after collection, using a Varian CP-3800 chromatograph, with a thermal conductivity detector (TCD), FID (Flame Ionization Detector) and a PoraPLOT column. The chromatograph was calibrated using certified standards purchased from White Martins (Praxair). We use three calibration ranges for each gas: certified standard n. 2432/11 (1,98 mg/L for $\mathrm{CH}_{4}$ and $400 \mathrm{mg} / \mathrm{L}$ for $\left.\mathrm{CO}_{2}\right)$, certified standard n. 2440/11 (20,1 mg/L 


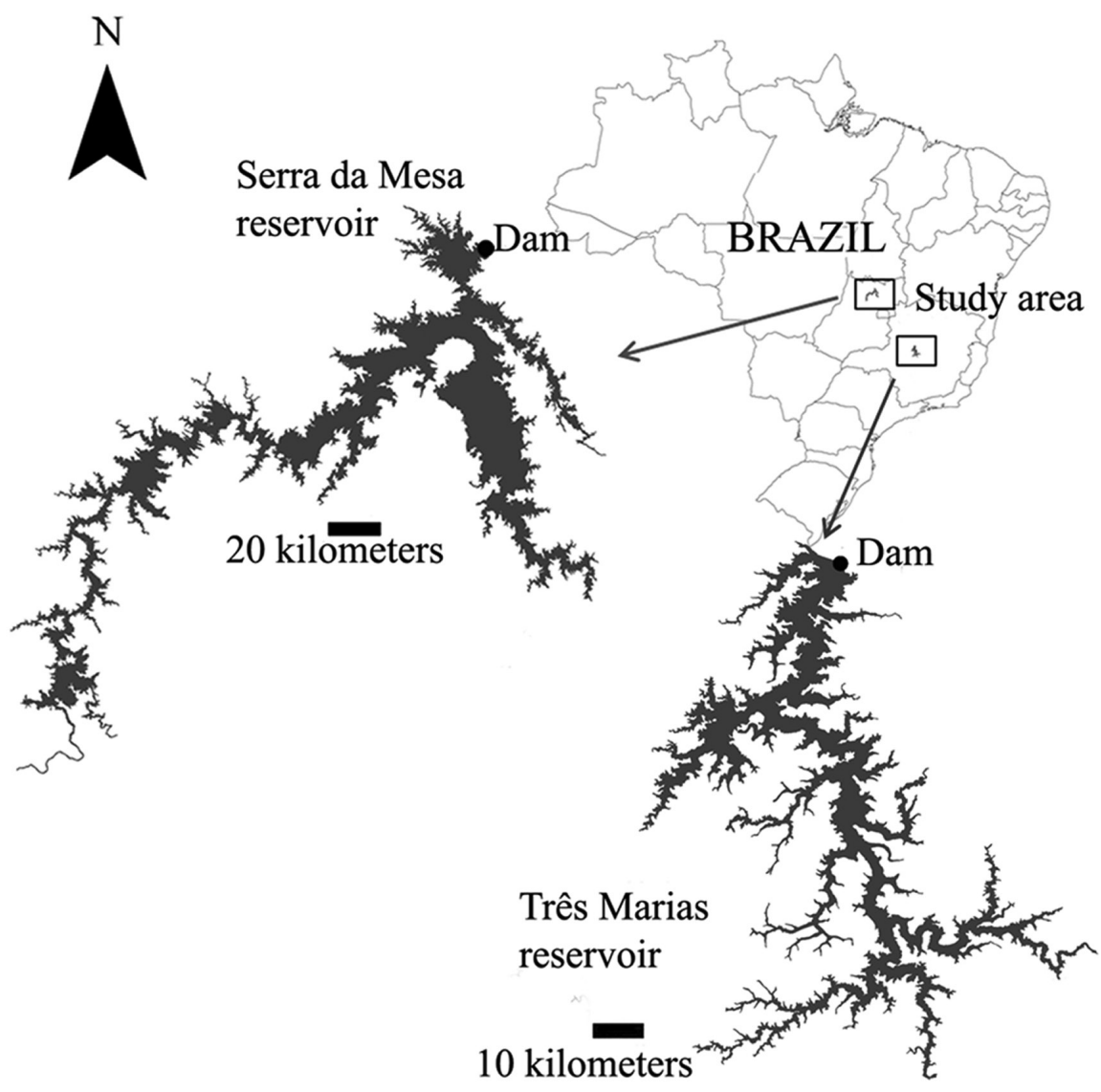

Figure 1. Geographical locations of Serra da Mesa and Três Marias Reservoirs.

Table 1. Sampling sites of reservoirs studied.

\begin{tabular}{cc}
\hline Três Marias Reservoir & Serra da Mesa Reservoir \\
\hline May, 2011 (48 sampling sites) & July, 2011 (46 sampling sites) \\
August, 2011 (47 sampling sites) & October, 2011 (42 sampling sites) \\
December, 2011 (46 sampling sites) & January, 2012 (37 sampling sites) \\
March, 2012 (45 sampling sites) & April, 2012 (37 sampling sites) \\
\hline
\end{tabular}

for $\mathrm{CH}_{4}$ and $602 \mathrm{mg} / \mathrm{L}$ for $\mathrm{CO}_{2}$ ) and certified standard n. $2442 / 11\left(50,2 \mathrm{mg} / \mathrm{L}\right.$ for $\mathrm{CH}_{4}$ and $998 \mathrm{mg} / \mathrm{L}$ for $\left.\mathrm{CO}_{2}\right)$

The rate of gas concentration increase within the chamber, and thus the diffusive flux, was determined by linear regression of concentration/time data sets (IEA, 2012). According to the IEA guidelines, fluxes were considered valid only when the regression coefficient $\left(\mathrm{R}^{2}\right)$ was greater than 0.85 the root-mean-square error was less than 0.11 (IEA, 2012). The samples that not meet these requirements were discarded.

The Kruskal-Wallis test was used to verify possible differences in emissions between the two reservoirs and to check for differences among the sampling campaigns of each reservoir. "R statistic" software was used for statistical assessment (The R Foundation, 2012).

\section{Results}

Of 162 fluxes for each gas has measured at Serra da Mesa Reservoir, $5 \%$ of fluxes of $\mathrm{CH}_{4}$ and $9 \%$ of $\mathrm{CO}_{2}$ were discarded. Considering the whole sample period, $\mathrm{CH}_{4}$ emissions ranged from 0.530 to $396.96 \mathrm{mg} \cdot \mathrm{m}^{-2} \cdot \mathrm{d}^{-1}$ and $\mathrm{CO}_{2}$ emissions ranged from $-1,738.33$ to $11,166.61 \mathrm{mg} \cdot \mathrm{m}^{-2} \cdot \mathrm{d}^{-1}$.

In Três Marias Reservoir we have measured $186 \mathrm{CH}_{4}$ fluxes for each gas, of which, $10 \%$ of fluxes of $\mathrm{CH}_{4}$ and $13 \%$ of $\mathrm{CO}_{2}$ were discarded. $\mathrm{CH}_{4}$ emissions in Três Marias ranged from 0.720 to $2,578.03 \mathrm{mg} \cdot \mathrm{m}^{-2} \cdot \mathrm{d}^{-1}$ and $\mathrm{CO}_{2}$ emission ranged from $-3,037.80$ to $11,516.64 \mathrm{mg} \cdot \mathrm{m}^{-2} \cdot \mathrm{d}^{-1}$. The fluxes measurements from four field campaigns are shown in Table 2.

Figure 2 shows historical data series of the rainfall distribution 17 years (from 1975 to 1992 and 2011 to 
Table 2. Median values of diffusive fluxes $\left(\mathrm{mg} \cdot \mathrm{m}^{2} \cdot \mathrm{d}^{-1}\right)$.

\begin{tabular}{lccccc}
\hline & & $\mathbf{C H}_{4}$ emission & Range & CO $_{2}$ emission & Range \\
\hline Serra da Mesa & $\mathrm{Jan} / 12$ & $6.13(36)$ & $3.82-10.88$ & $2,185.41(32)$ & $-1,542.51-9,526.49$ \\
Reservoir & $\mathrm{Apr} / 11$ & $3.83(37)$ & $2.13-7.43$ & $1,145.66(37)$ & $-1,738.33-4,570,52$ \\
& $\mathrm{Jul} / 11$ & $7.87(42)$ & $0.530-396.96$ & $3,215.39(36)$ & $870,82-11,166.61$ \\
& $\mathrm{Out} / 11$ & $9.22(39)$ & $1.73-68.77$ & $306,81(41)$ & $-776,34-1,349.58$ \\
Três Marias & $\mathrm{Mar} / 12$ & $5.51(40)$ & $1.53-172.53$ & $1,655.21(35)$ & $-3,037.80-11,516.64$ \\
Reservoir & $\mathrm{May} / 11$ & $6.12(43)$ & $0.720-150.16$ & $1,014.21(44)$ & $-721,29-7,860.39$ \\
& $\mathrm{Aug} / 11$ & $7.27(45)$ & $0.890-2,578.03$ & $-370.15(39)$ & $-873,46-9,776.49$ \\
& Nov/11 & $10.78(38)$ & $2.73-85.81$ & $497.62(43)$ & $-1,417.57-11,068.53$ \\
\hline
\end{tabular}

( ) The numbers in parentheses represent samples valid in each sampling campaign.
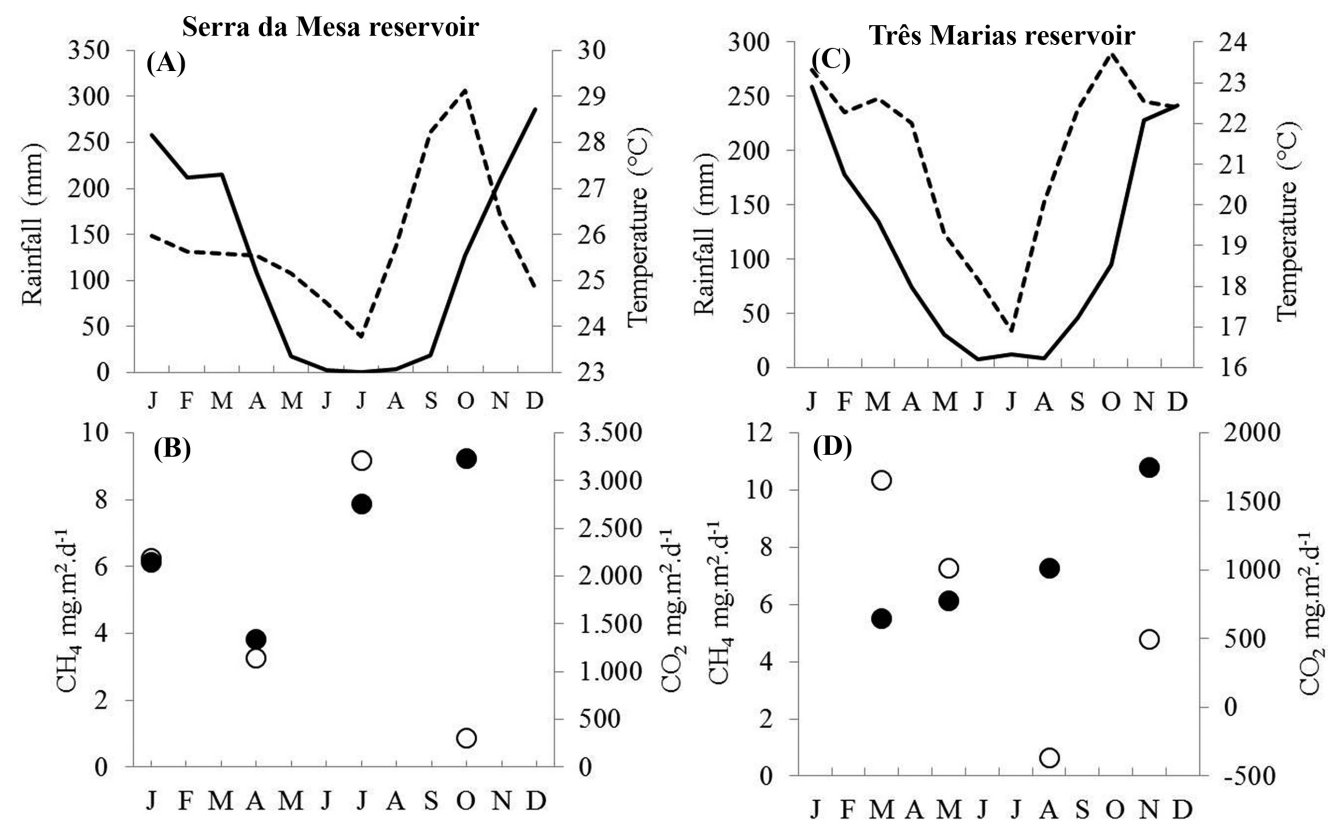

Figure 2. (A) and (B) refer to Serra da Mesa Reservoir while (C) and (D) Tres Marias Reservoir. In the horizontal axes are the months of the year. Solid lines represent monthly average rainfall and the lines segmented monthly average temperature. The blacks circles represent the medians of $\mathrm{CH}_{4}$ emissions and the open circles the median of $\mathrm{CO}_{2}$ emissions.

2012 of Três Marias and from 1994 to 2012 of Serra da Mesa) (ANA, 2013) and other series of 7 years (2004 to 2010 in both reservoirs) for temperature (INMET, 2013) in regions of the reservoirs as well as the median emission measurements. And as shown in Figure 3 we can see the median values and the outliers of $\mathrm{CH}_{4}$ emissions in both reservoirs. The use of median results as robust description of gas fluxes and comparison of others central tendency statistical descriptors can be read in (Damazio et al., 2013).

In this current study we have made comparisons of measured fluxes among the period studied. Regarding the comparison of $\mathrm{CH}_{4}$ fluxes, statistically significant distinctions between the periods studied were not found in Três Marias Reservoir (see Table 3).

We can say the same thing for the comparisons of $\mathrm{CH}_{4}$ fluxes among sampling campaigns in the Serra da Mesa Reservoir. An exception was observed in the fluxes

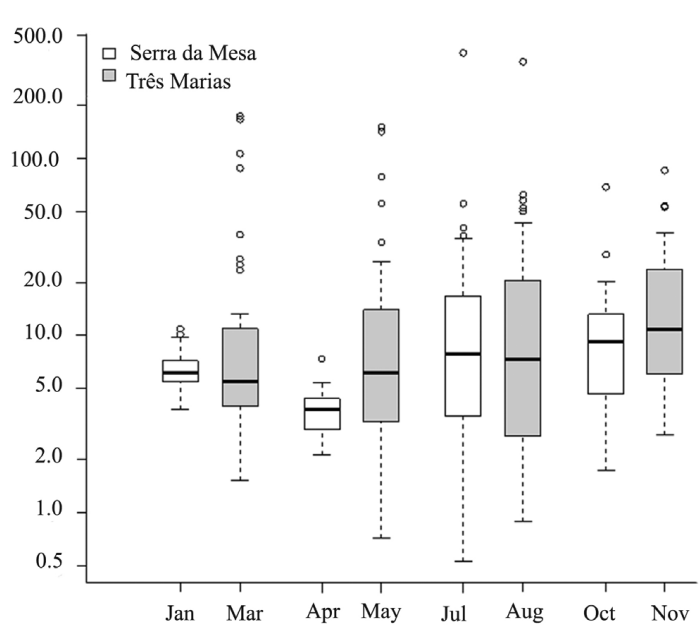

Figure 3. Box plot showing median $\mathrm{CH}_{4}$ emissions from the sampling campaigns in the two reservoirs studied. 
measured in April, which was particularly lower than in other periods (see Table 4).

The Figure 4 suggest a certain seasonality of $\mathrm{CO}_{2}$ emission in the Serra da Mesa Reservoir', due to differences among the fluxes from rainy-transition (January vs. April and October) and dry-transition (April vs July and October). Furthermore, emissions measured in transition months are different between themselves (April vs. October). (see Table 5).

The Três Marias Reservoir showed no seasonality with regards to $\mathrm{CO}_{2}$ emission, since we found no statistically significant difference, except for the emissions measured in May and August (see Table 6).

\section{Discussion}

In 1998 and 1999, Santos et al. (2006) measured diffusive emission at Serra da Mesa (range from -6,048 to $10,178 \mathrm{mg} \cdot \mathrm{m}^{-2} \cdot \mathrm{d}^{-1}$ to $\mathrm{CH}_{4}$ and $-5,360$ to $5,903 \mathrm{mg} \cdot \mathrm{m}^{-2} \cdot \mathrm{d}^{-1}$ to $\mathrm{CO}_{2}$ ) and Três Marias Reservoir (range from 0.660 to $241 \mathrm{mg} \cdot \mathrm{m}^{-2} \cdot \mathrm{d}^{-1}$ to $\mathrm{CH}_{4}$ and $-10,060$ to $7,346 \mathrm{mg} \cdot \mathrm{m}^{-2} \cdot \mathrm{d}^{-1}$ to $\mathrm{CO}_{2}$ ). Thus, the highest emissions that we found in the present study were higher than those found by Santos et al. (2006) in the previous study, with the exception of $\mathrm{CH}_{4}$ emissions in Serra da Mesa, which in this study had lower values.

The emissions peak in the first years after filling a reservoir tends to decrease and to stabilize over the subsequent years. In older reservoirs (over 10 years) in boreal and temperate regions, emissions of greenhouse gases are similar to natural lakes. However, in the tropics, the time to return to natural values may be longer, depending on the water quality (Tremblay et al., 2005). We suggest that both the natural variations and external anthropogenic factors, such as the organic material supply, are contributing to maintain high value in the Serra da Mesa Reservoir and Três Marias Reservoir, even 13 years after these early studies (Santos et al., 2009; Fonseca, 2010; Chandrasekera, 2000).

The results shown in Figure 2 suggest that there is a general trend of increase in median values of $\mathrm{CH}_{4}$ emissions

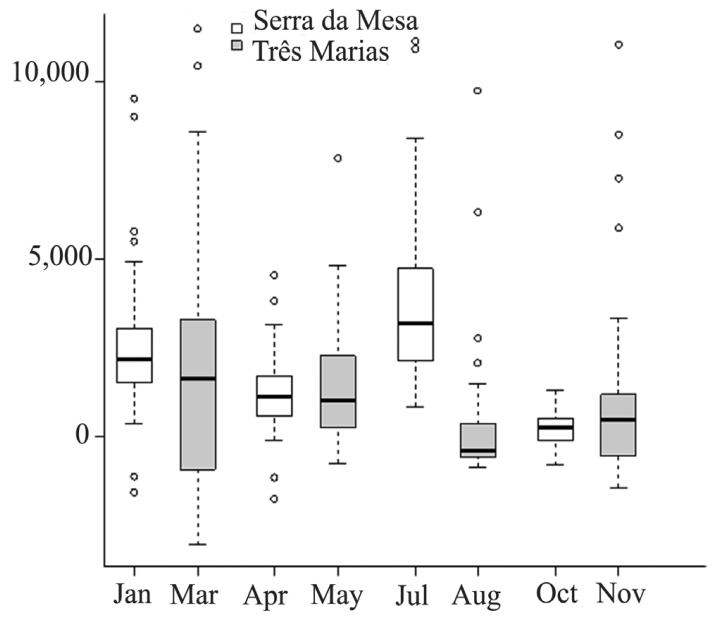

Figure 4. Box plot showing $\mathrm{CO}_{2}$ emissions along the sampling campaigns in the two reservoirs studied. in both reservoirs throughout the year, recording the lowest in April and highest in October despite being in the same hydrologic period and confirmed by the statistically significant differences in the flow of $\mathrm{CH}_{4}$. However in Três Marias Reservoir, the lowest value was recorded in March (end of the rainy season and very close to the rainy-dry transition season) and the highest in November (beginning of the rainy season and the end of the period of dry-rainy transition). We suggest that this trend of emissions are somehow related to transitional periods due to changes in the pattern of temperature and rainfall.

When we compare the $\mathrm{CH}_{4}$ emission shown in Figure 3, considering the significance level of $<0.05$, we found no statistically significant difference between the two reservoirs studied (Kruskal-Wallis chi-squared $=3.8217$, df $=1$, $\mathrm{p}$-value $=0.0509)$. However, this value was considered borderline for the test, since the observed value of the test statistic is slightly smaller than the critical value and this must be exceeded to be considered a statistically significant difference (SMR-TMR Difference observed $=20.4066$ critical difference $=20.45932$ Result $=$ There are difference). On the other hand the $\mathrm{CO}_{2}$ fluxes between the reservoirs studied showed statistically significant differences (Kruskal-Wallis chi-squared $=21.7085, \mathrm{df}=1$, p-value

Table 3. Results of comparisons of $\mathrm{CH}_{4}$ fluxes between the sampling campaigns conducted in Três Marias Reservoir. P-value 0.06.

\begin{tabular}{|c|c|c|c|}
\hline \multicolumn{4}{|c|}{$\begin{array}{c}\text { Três Marias Reservoir - Kruskal-Wallis multiple } \\
\text { comparison test }\end{array}$} \\
\hline Period & $\begin{array}{c}\text { Difference } \\
\text { observed }\end{array}$ & $\begin{array}{c}\text { critical } \\
\text { difference }\end{array}$ & \\
\hline Aug-Marc & 1.288 & 27.53579 & No \\
\hline Aug-May & 6.31 & 27.8 & No \\
\hline Aug-Nov & 21.425439 & $28.7^{\prime}$ & No \\
\hline Mar-May & 5.02894 & 27.85413 & No diff \\
\hline Mar-Nov & 22.714327 & 28.77596 & No difference \\
\hline May-Nov & 27.743268 & 29.08073 & No difference \\
\hline
\end{tabular}

Table 4. Results of comparisons of $\mathrm{CH}_{4}$ fluxes among the sampling campaigns in the Serra da Mesa Reservoir. $\mathrm{P}$-value $<0.05$.

\begin{tabular}{|c|c|c|c|}
\hline \multicolumn{4}{|c|}{$\begin{array}{c}\text { Kruskal-Wallis multiple comparison test to } \mathrm{CH}_{4} \\
\text { emission fromSerra da Mesa Reservoir }\end{array}$} \\
\hline Period & $\begin{array}{c}\text { Difference } \\
\text { observed }\end{array}$ & $\begin{array}{c}\text { critical } \\
\text { difference }\end{array}$ & Result \\
\hline Apr-Jan & 45.507132 & 27.54622 & $\begin{array}{l}\text { There are } \\
\text { difference }\end{array}$ \\
\hline Apr-Jul & 52.398005 & 26.53021 & $\begin{array}{l}\text { There are } \\
\text { difference }\end{array}$ \\
\hline Apr-Oct & 56.525295 & 27.00389 & $\begin{array}{l}\text { There are } \\
\text { difference }\end{array}$ \\
\hline Jan-Jul & 6.890873 & 26.72540 & No difference \\
\hline Jan-Oct & 11.018162 & 27.19567 & No difference \\
\hline Jul-Oct & 4.127289 & 26.16606 & No difference \\
\hline
\end{tabular}


Table 5. Comparison of $\mathrm{CO}_{2}$ emissions among sampling campaigns from Serra da Mesa Reservoir. p-value $<0.05$.

\begin{tabular}{|c|c|c|c|}
\hline \multicolumn{4}{|c|}{$\begin{array}{l}\text { Kruskal-Wallis multiple comparison test to } \\
\mathrm{CO}_{2} \text { emissions from Serra da Mesa Reservoir }\end{array}$} \\
\hline Period & $\begin{array}{c}\text { Difference } \\
\text { observed }\end{array}$ & $\begin{array}{c}\text { critical } \\
\text { difference }\end{array}$ & Result \\
\hline Apr-Jan & 28.74662 & 26.9345 & $\begin{array}{l}\text { There are } \\
\text { differences }\end{array}$ \\
\hline Apr-Jul & 49.26051 & 26.11987 & $\begin{array}{l}\text { There are } \\
\text { differences }\end{array}$ \\
\hline Apr-Oct & 33.20765 & 25.29974 & $\begin{array}{l}\text { There are } \\
\text { differences }\end{array}$ \\
\hline Jan-Jul & 20.51389 & 27.10752 & No difference \\
\hline Jan-Oct & 61.95427 & 26.31820 & $\begin{array}{l}\text { There are } \\
\text { differences }\end{array}$ \\
\hline Jul-Oct & 82.46816 & 25.48378 & $\begin{array}{l}\text { There are } \\
\text { differences }\end{array}$ \\
\hline
\end{tabular}

Table 6. Comparison of $\mathrm{CO}_{2}$ emissions among sampling campaigns from Três Marias Reservoir. P-value $<0.05$.

\begin{tabular}{cccl}
\hline \multicolumn{4}{c}{$\begin{array}{r}\text { Kruskal-Wallis multiple comparison test to CO } \\
\text { emissions from Três Marias Reservoir }\end{array}$} \\
\hline Period & $\begin{array}{c}\text { Difference } \\
\text { observed }\end{array}$ & $\begin{array}{c}\text { critical } \\
\text { difference }\end{array}$ & \multicolumn{1}{c}{ Result } \\
\hline Aug-Mar & 18.08718 & 28.63825 & No difference \\
Aug-May & 34.28263 & 27.05063 & $\begin{array}{l}\text { There are } \\
\text { differences }\end{array}$ \\
Aug-Nov & 11.92904 & 27.19802 & No difference \\
Mar-May & 16.19545 & 27.85801 & No difference \\
Mar-Nov & 6.15814 & 28.00116 & No difference \\
May-Nov & 22.35359 & 26.37522 & No difference \\
\hline
\end{tabular}

$=3.17^{-6}$ ) possibly due to the median values obtained in the months of August in Três Marias Reservoir and July in Serra da Mesa reservoir (Table 2).

Greenhouse gases fluxes from both hydroelectric reservoirs and natural lakes showed great variability in their values. For example, Galy-Lacaux et al. (1997) measured $\mathrm{CH}_{4}$ diffusive fluxes in Petit Saut (French Guiana) that ranged from 120 to $3.230 \mathrm{mg} \cdot \mathrm{m}^{-2} \cdot \mathrm{d}^{-1}$; Roehm and Tremblay (2006), measured $\mathrm{CO}_{2}$ fluxes two large dams in Canada (La Grande 2 and La Grande 3) with ranges between 80 and $1,800 \mathrm{mg} \cdot \mathrm{m}^{-2} \cdot \mathrm{d}^{-1}$ and 400 and 1,500 mg.m $\mathrm{m}^{-2} \cdot \mathrm{d}^{-1}$; Therrien et al. (2005) measured $\mathrm{CO}_{2}$ flux in Arizona - USA that ranged between $-1,116$ and $3,104 \mathrm{mg} \cdot \mathrm{m}^{-2} \cdot \mathrm{d}^{-1}$ and Duchemim et al. (2001) measured $\mathrm{CH}_{4}$ fluxes in the range 12 to $65 \mathrm{mg} \cdot \mathrm{m}^{-2} \cdot \mathrm{d}^{-1}$ in an old reservoir in the Amazon region, Brazil.

In the present study, the $\mathrm{CO}_{2}$ fluxes measured in January (rainy season) and July (dry season) in Serra Mesa Reservoir (as shown in Figure 4) proved to be indistinguishable from each other, but they are different when compared to April and October which are transition months from wet to dry and from dry to wet season, respectively. Moreover, the
$\mathrm{CO}_{2}$ emission measured in April and October also showed differences between themselves. We attribute this large natural range of data as well as specific characteristics of each study period, for example, by the fact that it rains more in October than in April, even though these two months are in transition periods.

Thus, we believe that this natural variability of the phenomenon of gas emissions in the air-water interface contributes to find results that are discordant at first glance, like an apparent lack of seasonality of $\mathrm{CH}_{4}$ emission in both reservoirs, even though they almost doubled over the months analyzed. Also relevant was the fact that the Serra da Mesa reservoir and the Três Marias Resevoir showed negative $\mathrm{CO}_{2}$ emissions by 3 of the 4 campaigns in Serra da Mesa and all periods in Três Marias (Table 2). This fact is linked to the intense metabolism of $\mathrm{CO}_{2}$ convert it to organic matter by photosynthetic organisms and thus they influence the chemical gradient of $\mathrm{CO}_{2}$ in the air-water interface.

\section{Conclusion}

We concluded that the $\mathrm{CH}_{4}$ fluxes were statistically indistinguishable in all analyzed hydrological periods, although the median have increased over the periods studied in both reservoirs. However during the month of April, which is a transition period in Serra da Mesa, fluxes were shown to be distinct from other periods studied, suggesting that there may be some component in this period that somehow influences the changes in $\mathrm{CO}_{2}$ emissions standards.

Corroborating with this idea, the $\mathrm{CO}_{2}$ fluxes measured in Serra da Mesa reservoir were distinct when comparing the periods of transition versus rainy and dry periods. We believe that perhaps this is due to seasonal influences changes in rainfall and temperatures.

Finally, the hydropower reservoirs are emitters or absorbers of carbon as $\mathrm{CO}_{2}$, which may in the long term balance the positive emissions beginning of the filling period. We believe that further measurements in greenhouse gas emissions are needed in order to better understand the variability of emissions.

In addition, other factors must be better analyzed as the input of different carbon fractions and their concentrations in the lake, the influence of meteorological factors, the human interventions such as land use basin which can exert influence and contribution with this allocthonus organic matter on greenhouse gases emissions.

\section{Acknowledgements}

CHESF, which financed this research study through the Project Greenhouse Gas Emission Monitoring from for Hydropower Reservoirs and the National Council for Scientific and Technological Development (CNPq) for awarding a doctoral study grant to the first author of this paper. We thank the National Council for Scientific and Technological Development (CNPq) for the research 
productivity grant awarded to the second author of this paper. We thank the National Science and Technology Institute (INCT - Climate Change - Emissions from Lakes and Reservoirs Sub-Project) for awarding a grant to the fifth and sixth authors of this paper. We thank Dr. John Edmund Lewis Maddock for his important discussion on this paper.

\section{References}

ABRIL, G., GUÉRIN, F., RICHARD, S., DELMAS, R., GALYLACAUX, C., GOSSE, P., TREMBLAY, A., VARFALVY, L., SANTOS, MA. and MATVIENKO, B., 2005. Carbon dioxide and methane emissions and the carbon budget of a 10-year old tropical reservoir (Petit Saut, French Guiana). Global Biogeochemical Cycles, vol. 19, no. 4, p. GB4007. http://dx.doi. org/10.1029/2005GB002457.

Agência Nacional de Águas - ANA, 2013. Hidro Web Sistema de Informações hidrológicas. ANA. Available from: <http:// hidroweb.ana.gov.br/>. Access in: 4 Feb. 2013.

BARTLETT, KB. and HARRISS, RC., 1993. Review and Assessment of Methane Emissions from Wetlands. Chemosphere, vol. 26, no. 1-4, p. 261-320. http://dx.doi.org/10.1016/0045-6535(93)90427-7.

BARTLETT, KB., CRILL, PM., BONASSI, JA., RICHEY, JE. and HARRISS, RC., 1990. Methane flux from the Amazon River floodplain: emissions during the rising water. Journal of Geophysical Research, vol. 95, no. D10, p. 16773-16788. http:// dx.doi.org/10.1029/JD095iD10p16773.

BARTLETT, KB., CRILL, PM., SEBACHER, DI., HARRISS, RC., WILSON, JO. and MELACK, JM., 1988. Methane flux from the central Amazonian floodplain. Journal of Geophysical Research, vol. 93, no. D2, p. 1571-1582. http://dx.doi.org/10.1029/ JD093iD02p01571.

Brasil. Ministério de Minas e Energia - MME, 2012. Balanço Energético Nacional 2012: Ano base 2011. Rio de Janeiro: Empresa de Pesquisa Energética.

CHANDRASEKERA, CMMMK., 2000. Investigation of Hydrological Responses to Land Use Changes in Two Sub Catchments of the Upper Mahaweli Catchment. Sri Lanka: Postgraduate Institute of Agriculture, University of Peradeniya. Unpublished M. Phil Thesis.

CICERONE, RJ. and OREMLAND, RS., 1988. Biogeochemical aspects of atmospheric methane. Global Biogeochemical Cycles, vol. 2, no. 4, p. 299-327. http://dx.doi.org/10.1029/GB002i004p00299.

COLE, JJ. and CARACO, NF., 1998. Atmospheric exchange of carbon dioxide in a low wind oligotrophic lake measured by the addition of SF6. Limnology and Oceanography, vol. 43, no. 4, p. 647-656. http://dx.doi.org/10.4319/10.1998.43.4.0647.

DAMAZIO, JM., SANTOS, MA., XAVIER, VL., MEDEIROS, AM., MARCELINO, AA., AMORIM, MA., BEZERRA, CS., ROGERIO, JP., SIKAR, DM., SIKAR, EM. and MATVIENKO, B., 2013. Uso da mediana para estimativa robusta de taxa de emissão difusiva de gases de efeito estufa em reservatórios a partir de medições pontuais com câmaras flutuantes espacialmente distribuídas. In XX Simpósio Brasileiro de Recursos Hídricos, 2013. Bento Gonçalves. Bento Gonçalves: Associação Brasileira de de Recurso Hídricos.

DEL GIORGIO, PA., COLE, JJ., CARACO, NF. and PETERS, RH., 1999. Linking planktonic biomass and metabolism to net gas fluxes in northern temperate lakes. Ecology, vol. 80, no. 4, p.
1422-1431. http://dx.doi.org/10.1890/0012-9658(1999)080[1422:LP BAMT]2.0.CO;2.

DEVOL, AH., RICHEY, JE., CLARK, WA., KING, SL. and MARTINELLI, LA., 1988. Methane emission to the troposphere from the Amazon floodplain. Journal of Geophysical Research, vol. 93, no. D2, p. 1583-1592. http://dx.doi.org/10.1029/ JD093iD02p01583.

DEVOL, AH., RICHEY, JE., FORSBERG, BR. and MARTINELLI, LA., 1990. Seasonal dynamics in methane emissions from the Amazon River floodplain to the troposphere. Journal of Geophysical Research, vol. 95, no. D10, p. 16417-16426. http:// dx.doi.org/10.1029/JD095iD10p16417.

DLUGOKENCKY, E. and TANS, P., 2012. Trends in Atmospheric Carbon Dioxide. Avaiable from: http://www.esrl.noaa.gov/gmd/ ccgg/trends. Access in: 25 Feb. 2013.

DUCHEMIM, E., LUCOTTE, M., CANUEL, R., QUEIROZ, AG., ALMEIDA, DC., PEREIRA, HC. and DEZINCURT, J., 2001. Comparison of greenhouse gas emissions from an old tropical reservoir with those from other reservoirs worldwide. Verhandlungen des Internationalen Verein Limnologie., vol. 27, p. 1391-1395.

DUMESTRE, JF., CASAMAYOR, EO., MASSANA, R. and PEDRÓS-ALIÓ, C., 2002. Change in bacterial and archaeal assemblages in an equatorial river induced by the water eutrophication of Petit Saut dam reservoir (French Guiana). Aquatic Microbial Ecology, vol. 26, p. 209-221. http://dx.doi.org/10.3354/ame026209.

DUMESTRE, JF., VAQUER, A., GOSSE, P., RICHARD, S. and LABROUE, L., 1999. Bacterial ecology of a young equatorial hydroelectric reservoir (Petit Saut, French Guiana). Hydrobiologia, vol. 400, p. 75-83. http://dx.doi.org/10.1023/A:1003707129170.

FONSECA, GAB., 2010. Contribuição antrópica na poluição de reservatórios hidrelétricos: o caso da usina de São Simão-GO/ $M G$. Rio de Janeiro: Universidade Federal do Rio de Janeiro. Dissertação de Mestrado em Planejamento Energético.

GALY-LACAUX, C., DELMAS, R., JAMBERT, C., DUMESTRE, JF., LABROUE, L., RICHARD, S. and GOSSE, P., 1997. Gaseous emissions and oxygen consumption in hydroelectric dams: a case study in French Guyana. Global Biogeochemical Cycles, vol. 11, no. 4, p. 471-483. http://dx.doi.org/10.1029/97GB01625.

GUÉRIN, F., ABRIL, G., RICHARD, S., BURBAN, B., REYNOUARD, C., SEYLER, P. and DELMAS, R., 2006. Methane and carbon dioxide emission from tropical reservoir: Significance of downstream rivers. Geophysical Research Letters, vol. 33, no. 21, p. L21407. http://dx.doi.org/10.1029/2006GL027929.

HAMILTON, SK., SIPPE, SJ. and MELACK, JM., 1995. Oxygen depletion and carbon dioxide and methane production in waters of the Pantanal wetlands of Brazil. Biochemistry, vol. 30, no. 2, p. 115-141.

Instituto Nacional de Metereologia - INMET, 2013. Banco de dados meteorológicos para ensino e pesquisa. INMET. Avaiable from: http://www.inmet.gov.br/portal/index.php?r=bdmep/bdmep. Access in: 4 Feb. 2013.

Intergovernmental Panel On Climate Change - IPCC., 2007. Fourth Assessment Report: Climate Change. Cambridge: Working Group I: The Physical Science Basis.

International Energy Agency - IEA, 2012. Guidelines for Quantitative Analysis of Net GHG Emissions from Reservoirs. Measurement Programs and Data Analysis. Implementing Agreement for 
Hydropower technologies and Programmes. Paris: International Energy Agency.

KELLY, CA., RUDD, JWM., BODALY, RA., ROULET, NP., ST. LOUIS, VL., HEYES, A., MOORE, TR., SCHIFF, S., ARAVENA, R., SCOTT, KJ., DYCK, B., HARRIS, R., WARNER, B. and EDWARDS, G., 1997. Increases in fluxes of greenhouse gases and methyl mercury following flooding of an experimental reservoir. Environmental Science \& Technology, vol. 31, no. 5, p. 13341344. http://dx.doi.org/10.1021/es9604931.

ROEHM, C. and TREMBLAY, A., 2006. Role of turbines in the carbon dioxide emissions from two boreal reservoirs, Quebec, Canada. Journal of Geophysical Research, vol. 111, no. D24, p. D24101. http://dx.doi.org/10.1029/2006JD007292.

ROLAND, F., VIDAL, LO., PACHECO, FS., BARROS, NO., ASSIREU, A., OMETTO, JPHB., CIMBLERIS, ACP. and COLE, JJ., 2010. Variability of carbon dioxide flux from tropical (Cerrado) hydroelectric reservoirs. Aquatic Sciences, vol. 72, no. 3, p. 283293. http://dx.doi.org/10.1007/s00027-010-0140-0.

ROSA, LP. SCHAEFFER, R. and SANTOS, MA., 1994. Projeto ambiental das hidrelétricas na Amazônia: emissões de metano e dioxido de carbono de hidrelétricas na Amazônia comparada às da termelétricas equivalents. Rio de Janeiro: PPE, ELETROBRAS. Relatório 1-94.

ROSA, LP., SANTOS, MA., MATIVIENKO, B., SIKAR, E., LOURENÇO, RSM. and MENEZES, CF., 2003. Biogenic gas production from major Amazon reservoirs, Brazil. Hydrological Processes, vol. 17, no. 7, p. 1443-1450. http://dx.doi.org/10.1002/ hyp. $1295 .</$ jrn $>$.

RUDD, JWM., HARRIS, R., KELLY, CA. and HECKY, RE., 1993. Are hydroelectric reservoirs significant sources of greenhouse gases? Ambio, vol. 22, p. 246-248.

SANTOS, EO., SILVA, C., SANTOS, MA., MATVIENKO, B., ROCHA, CHEDA., ROSA, LP., SIKAR, E., SILVA, MB. and BENTES, AMP., 2009. The importance of land use change analysis in the greenhouse gases emissions from hydroelectric reservoirs. Verhandlungen des Internationalen Verein Limnologie, vol. 30 , no. 6 , p. 845-849.

SANTOS, MA., ROSA, LP., SIKAR, B., SIKAR, E. and SANTOS, EO., 2006. Gross greenhouse gas fluxes from hydro-power reservoir compared to thermo-power plants. Energy Policy, vol. 34, no. 4, p. 481-488. http://dx.doi.org/10.1016/j.enpol.2004.06.015.

SEGERS, R., 1998. Methane production and methane consumption: a review of processes underlying wetland methane fluxes. Biogeochemistry, vol. 41, no. 1, p. 23-51. http://dx.doi. org/10.1023/A:1005929032764.

STRIEGL, RG. and MICHMERHUIZEN, CM., 1998. Hydrologic influence on methane and carbon dioxide dynamics at two north - central Minnesota lakes. Limnology and Oceanography, vol. 43, no. 7, p. 1519-1529. http://dx.doi.org/10.4319/lo.1998.43.7.1519.

The R Foundation, 2012. R: A language and environment for statistical computing. Vienna: R Foundation for Statistical Computing. Available from: $<$ http://www.R-project.org/>. Access in: 13 Mar. 2013.

THERRIEN, J., TREMBLAY, A. and JACQUES, RB., 2005. CO2 emissions from semi-arid reservoirs and natural aquatic ecosystems. In TRAMBLAY, A., VARFALVY, L. and ROEHM, C. (Eds.). Greenhouse gas emissions: fluxes and processes, hydroelectric reservoirs and natural environments. Berlin: Springer-Verlag. p. 233-250. http://dx.doi.org/10.1007/978-3-540-26643-3_10.

TRANVIK, LJ., DOWNING, JA., COTNER, JB., LOISELLE, SA., STRIEGL, RG., BALLATORE, TJ., DILLON, P., FINLAY, K., FORTINO, K., KNOLL, LB., KORTELAINEN, PL., KUTSER, T., LARSEN, S., LAURION, I., LEECH, DM., MCCALLISTER, SL., MCKNIGHT, DM., MELACK, JM., OVERHOLT, E., PORTER, JA., PRAIRIE, Y., RENWICK, WH., ROLAND, F., SHERMAN, BS., SCHINDLER, DW., SOBEK, S., TREMBLAY, A., VANNI, MJ., VERSCHOOR, AM., VON WACHENFELDT, E. and WEYHENMEYER, GA., 2009. Lakes and reservoirs as regulators of carbon cycling and climate. Limnology and Oceanography, vol. 54, no. 6part2, p. 2298-2314. http://dx.doi. org/10.4319/1o.2009.54.6_part_2.2298.

TREMBLAY, A., THERRIEN, J., HAMLIN, B.,WICHMANN, E. and LEDREW, LJ., 2005. GHG from boreal reservoirs and natural aquatic ecosystems. In: TREMBLAY, A., VARFALY, L., ROEHM, C. and GARNEAU, M. (Eds). Greenhouse gas emissions: fluxes and processes, hydroelectric reservoirs and natural environments. New York: Springer-Verlag Berlin Heidelberg. http://dx.doi. org/10.1007/978-3-540-26643-3_9.

WHITMAN, WB., BOWEN, TL. and BOONE, DR., 2006. The methanogenic bacteria. In: DWORKIN, M., FALKOW, S., ROSENBERG, E., SCHLEIFER, KH. and STAKERBRANDT, E. (Eds). The prokaryots: an evolving electronic resource for the microbiological community. New York: Springer.

WUEBBLES, DJ. and HAYHOE, K., 2002. Atmospheric methane and global change. Earth-Science Reviews, vol. 57, no. 3-4, p. 177-210. http://dx.doi.org/10.1016/S0012-8252(01)00062-9. 